Meyerbeer's "L'Africaine": French Grand Opera and the Iberian Exotic Author(s): Jean Andrews

Source: The Modern Language Review, Vol. 102, No. 1 (Jan., 2007), pp. 108-124

Published by: Modern Humanities Research Association

Stable URL: http://www.jstor.org/stable/20467155

Accessed: 03-03-2016 10:11 UTC

\title{
REFERENCES
}

Linked references are available on JSTOR for this article:

http://www.jstor.org/stable/20467155?seq=1\&cid=pdf-reference\#references_tab_contents

You may need to $\log$ in to JSTOR to access the linked references.

Your use of the JSTOR archive indicates your acceptance of the Terms \& Conditions of Use, available at http://www.jstor.org/page/ info/about/policies/terms.jsp

JSTOR is a not-for-profit service that helps scholars, researchers, and students discover, use, and build upon a wide range of content in a trusted digital archive. We use information technology and tools to increase productivity and facilitate new forms of scholarship. For more information about JSTOR, please contact support@jstor.org. 


\section{MEYERBEER'S L'AFRICAINE: FRENCH GRAND OPERA AND THE IBERIAN EXOTIC}

Giacomo Meyerbeer's valedictory L'Africaine was first given posthumously at the Opéra de Paris on 28 April I 865. In this opera the Portuguese explorer Vasco da Gama is loved by Sélika, an enslaved Indian queen and the Africaine of the title, whom he buys at a slave market somewhere on the south-east coast of Africa and takes back to the Portuguese court. On his return to Lisbon, having lost his captain, Bartolomeu Dias, in a storm at the Cape of Good Hope, he pleads for finance for a new voyage of exploration, this time led by himself, on the basis of what he has seen so far. For his pains, and his less than pious attitude, he is thrown into the Inquisition jail at the behest of the influential clergy present at court. Sélika then saves his life in jail when her companion slave Nélusko threatens to kill him while he sleeps. However, Vasco, in his turn, loves and is loved by Donna Inèz, a lady of the Portuguese court whose father opposes their marriage because he considers da Gama to be a mere adventurer of no family. Inèz promptly secures Vasco's release from jail by agreeing to marry the powerful and hot-headed nobleman Don Pédro, whom her father has selected for her. In response, before he knows of her betrothal to Don Pédro and to show Inèz that she should have no jealousy of his attachment to Sélika, Vasco gives Sélika and Nélusko to her. Pédro then funds a voyage of his own to the Indies, with Inèz and several of her ladies on board and Sélika and Nélusko also included. Vasco follows their expedition in another ship to warn them of the dangers awaiting them as they round the Cape. As they near what is revealed as Sélika's kingdom, most probably the island of Madagascar, Nélusko is somehow complicit in a raid whereby Sélika's people take over the ship. ${ }^{1}$ Just before this, Vasco boards Pédro's craft but is greeted by outright hostility on Pédro's part, to the extent that he orders Vasco's execution, an instruction then lost in the subsequent fracas in which Don Pédro and all the other men, apart from Vasco, are put to death. Sélika is taken back to her kingdom and quickly proclaimed queen. When a disoriented Vasco then appears at her court, she immediately informs all and sundry that he is her husband, this in order to avoid his execution under laws decreeing death to any foreigner found in her territory. Unbeknownst, Inèz and her ladies all struggle ashore as well and are duly sentenced to death after being discovered near Sélika's court. Though all her ladies are killed by inhaling the poisonous fragrance of the manchineel tree, Inèz survives to confront Sélika, in a climactic duet. In the course of this encounter, Sélika magnanimously recognizes that Vasco's love for her was mere

I The ship is supposedly wrecked on reefs past the Cape of Good Hope; geographically, this would indicate their being off Madagascar and this as the place where the survivors land, but the culture into which they are all absorbed in the fourth act and in which Sélika is accepted as queen is quintessentially Indian. Gabriela Cruz is adamant that the location is Madagascar and that Nélusko is a Malagasy slave, though this is far from clear in the final version of the libretto: Gabriela Cruz, 'Laughing at History: The Third Act of Meyerbeer's L'Africaine', Cambridge Opera Fournal, I I (March I 999), 31-76 (p. 3i). John Roberts, meanwhile, is more equivocal, stressing the importance Meyerbeer laid on the Indian elements in his composition: John $\mathrm{H}$. Roberts, 'Meyerbeer: Le Prophète and L'Africaine', in The Cambridge Companion to Grand Opera, ed. by David Charlton (Cambridge: Cambridge University Press, 2003), pp. 208-33 (p. 226).

Modern Language Review, 102 (2007), 108-24

(C) Modern Humanities Research Association 2007 
gratitude, whereas his love for Inèz is true, and therefore sets them both free. In despair and accompanied by Nélusko, who, for his part, has always devotedly loved her, she withdraws and commits suicide under the deadly manchineel. The opera ends with a mournful duet between Sélika and her loyal servant.

The patchworked libretto for L'Africaine began life in 1837 in the hands of the then ubiquitous Eugène Scribe, who had been elected to the Académie Française in 1834 at the age of thirty-five. There was very little produced on the French stage at this time, whether grand opera, opéra comique, straight comedy, melodrama, or even ballet, which did not bear the mark of his seminal template for the 'well-made play', either as hands-on playwright/librettist or more distant shaper of material supplied by a team of subcontracted writers. In the context of grand opera, it was Scribe more than any other who, with his sensitivity to the taste of the audience of the time and his ability to make the most of nineteenth-century innovation in theatrical technology, engineered the theatrical success of grand opera in Paris through his work as librettist with the composers Auber, Halévy, and Meyerbeer himself.

The libretto for L'Africaine, a relatively early collaboration, passed through several revisions, the most important of which was a switch of title and plotline in $185 \mathrm{I}$ which introduced Vasco da Gama as the pivotal figure in the narrative (Cruz, p. 32). This conversion was due to no less than the great masterpiece of early modern Portuguese literature, Luís de Camões's Homeric epic Os Lusiadas, published in Lisbon in 1572 . Meyerbeer read this work in 1850-5I, then passed it on to Scribe, with the result that the entire opera changed orientation and became centred on the figure of da Gama (Cruz, p. 39). Camões's epic, written by a sometime servant of the Portuguese Crown and the seaborne empire which grew out of the Discoveries, recorded the grand scale of navigational and political achievement during the fifteenth and sixteenth centuries. 'Para Portugal ficou o eterno pregão da história, o monumento imperecível do seu passado', and this at a time when Portuguese power in Africa was waning and the kingdom itself was about to be annexed by Philip II of Spain after the disastrous North African military intervention of Dom Sebastião, whose body was, crucially for the Portuguese psyche from then on, lost in the Battle of Alcácer-Quivir (Ksar el Kebir, Morocco) in I 578. ${ }^{2}$ Camões's epic subsequently became the repository, for the subjugated Portuguese, of all their nation once was. Almost three centuries later, in French translation, it was evidently a key source for Meyerbeer and Scribe as they struggled to bring their own project to fruition.

After Scribe's death in I86I Meyerbeer enlisted the aid of the German playwright Charlotte Birch-Pfeiffer, on the understanding that her German verse would be translated into French by Joseph Duesberg. Later on, Meyerbeer employed the librettist Camille du Locle, who would also work on Verdi's Don Carlos, as collaborator on the project still known as Vasco da Gama. After Meyerbeer's death in May I 864 there was further tinkering by François-Joseph Fétis, the musicologist appointed by Meyerbeer's widow to oversee rehearsals and final alterations to the score. When the opera was eventually premiered,

\footnotetext{
${ }^{2}$ Theophilio Braga, Préfaçio, Os Lusiadas (edição I 88I) 〈www.lusiadas/gertrudes.com)[accessed 3 I July 2006].
} 
almost thirty years after its initial inception, with both its key creators dead, it had reverted to the now barely relevant title of L'Africaine. ${ }^{3}$ According to Roberts (p. 225), Fétis decided to reinstate the original title on the grounds that the Parisian public had long been anticipating an opera of that name from Meyerbeer.

It is important to remember the conditions under which grand opera, in particular the grand opera libretto, was produced in Paris at this time. As Nicholas White explains:

From the very beginning French grand opera librettos were conceived of not as immutable expressions of a particular Romantic génie but as malleable responses to the needs of the Paris Opéra and its composers, not least Auber, Halévy, Meyerbeer and Verdi. [. . . ] Grand opera librettos were not well-sealed artefacts; with neither the aura of the Romantic classic nor the autonomy of the 'well-made work' [. . . they served rather than dictated the process of production and performance. ${ }^{4}$

None the less, the influence of Scribe and his famously liberal-minded preoccupations is still clearly discernible in the finished product, which the Paris audience saw in $\mathrm{I}^{86}$. The performed version of $L$ 'Africaine raises a series of intertwined issues relating to race and religion, slavery and imperialism, both relevant to the spirit of Paris in the mid-186os and plainly identifiable, in hindsight, as part of the orientalizing tendency which Said so cogently singled out as a by-product of European colonial expansionism. ${ }^{5}$ Conveniently, of course, the culture ostensibly under scrutiny here is that of Portugal in the sixteenth century, not that of France in the nineteenth, and since this is a Portugal imagined for a French audience, the requirement to adhere to historical accuracy may be dispensed with. In any case, White points out that, as a general rule in the grand operas of Eugène Scribe, 'the influence of literature [. . .] was diluted in a freer association involving various fictional works and historical "facts"' (p. 48). He invokes Gerhard Anselm's view that

grand opera [had a] tendency to discount the public's knowledge of literature [. . .] it was no longer necessary for the audience at an opera to be familiar with classical mythology or to have read the libretto beforehand in order to follow the action. (White, pp. $426-27)^{6}$

It is thus apparent that grand opera functioned in a performance environment in which contextual knowledge has become secondary to emotional response, an emotional response in no small sense generated by what Simon Williams terms a 'prodigality' of spectacle which served as a 'powerful lure to draw audiences to the Opéra', often in spite of mediocre music, a weak libretto, and uninvolving action. $^{7}$

\footnotetext{
3 See Roberts, pp. 208, 222-23.

${ }^{4}$ Nicholas White, 'Fictions and Librettos', in The Cambridge Companion to Grand Opera (see Roberts, above), pp. 43-57, 426-28 (p. 47).

${ }^{5}$ White cites Said's identification of a cause-and-effect relationship between French colonial expansion and the orientalization of non-European colonized cultures in his description of L'Africaine (p. 5I).

${ }^{6}$ The reference is to Gerhard Anselm, The Urbanisation of Opera: Music Theatre in Paris in the Nineteenth Century (Chicago, IL: University of Chicago Press, I 998), p. 23.

7 Simon Williams, 'The Spectacle of the Past in Grand Opera', in The Cambridge Companion to Grand Opera (see Roberts, above), pp. 58-75 (p. 62).
} 
Under these conditions then, the representation of Portuguese history at the turn of the fifteenth into the sixteenth century, Scribe's 'facts', could not have been more approximate, yet the purpose to which they were moulded could not have been more explicit or indeed more applicable in a general sense to world affairs. For the purposes of the plot, Meyerbeer and Scribe assembled a patchwork of facts extracted from the history of the Portuguese Discoveries. As Gabriela Cruz notes (p. 3i), Meyerbeer and Scribe had done their research thoroughly and were well aware of the true course of da Gama's life and the attendant political context. Thus da Gama was, in fact, received by the Portuguese court in I 499 on his return from his first voyage to India with great rejoicing and duly raised to the nobility. During this voyage he stopped at various places on the south-east coast of Africa, finally picking up an Arab pilot, Ahmed Ibn Majid, in the Swahili city-state of Malindi (Kenya), who guided him across the Indian Ocean to Calicut. There was also an episode, as in L'Africaine, in which an African pilot from the coast of Mozambique attempted to lead the ship off course, but he was found out by the Portuguese crew, jumped ship, and swam to safety in Mombassa. When da Gama returned to Portugal, he left behind him a party of forty in Calicut, which was then ruled by the Hindu prince Zamorim, who had not looked very favourably on da Gama's expedition. After da Gama's departure in I 498, the Portuguese were put to death. In response, the Portuguese king, Dom Manuel I, fitted out a squadron of twenty ships for da Gama to return to India and avenge these killings. On this voyage he made colonies of the African cities of Mozambique and Sofala (Mozambique) on his way out before taking revenge on Calicut and returning to Portugal in 1503 . He was subsequently named Viceroy in Cochin, south of Calicut, and died there in 1525 .

In the opera Vasco has returned from a voyage resembling the 1488 rounding of the Cape of Good Hope led by Bartolomeu Dias, after which, in the plot, Dias is lost at sea; though in fact Dias perished in a storm on the return leg of the voyage of discovery led by Pedro Cabral which reached Brazil in 1500 . In the intervening years he founded trading posts and oversaw da Gama's I 497 expedition to India, even joining it as far as the Cape Verde Islands. The operatic Vasco is an unmarried, low-born, youthful hero (da Gama was born in 1460 or so), who comes before a Council of State in Lisbon to explain the posthumous success of Dias's voyage and plead for funding for a voyage of his own to explore further the possibilities opened up by having rounded the Cape. In the course of a very compact and entirely fictitious sequence of exchanges between Vasco and the members of the Council two highly contentious issues are highlighted: slavery and religious bigotry.

In a world where slavery was still a reality, especially in the plantations of the Americas, and at a time- the first half of the 1860 - - when it lay at the heart of a major internecine conflict, the American Civil War, L'Africaine makes a salient and, for the sixteenth century, anachronistic point about the plight of the slave. At the beginning of Act II there is an exchange between Sélika and Nélusko on the nature of slavery as a commodification of the human being which, in the midst of a shared discourse otherwise dealing with the contrasting demands of religion and love, might pass all but the most sharp-eared listener by. In the 
dungeon where all three are incarcerated, Sélika attempts to dissuade Nélusko from murdering the sleeping Vasco by reminding him of Vasco's humanity and generosity to them. Nélusko will accept none of this mitigation:

\begin{tabular}{ll} 
SÉLIKA & \multicolumn{1}{c}{ Ô ciel, que veux-tu faire, } \\
& C'est un prisonnier, comme nous! \\
NÉLUSKO C'est un chrétien, je les déteste tous. \\
SÉLIKA & Il fut notre sauveur, il est là sans défense! \\
NÉLUSKO & A prix d'or au marché, nous lui fûmes vendus! \\
& Voilà, tous ses bienfaits! Pour l'acheteur, jamais \\
& La marchandise n'eut de la reconnaissance! \\
Famais! jamais! & \\
SÉLIKA & Il t'acheta, c'est vrai! Mais touché de mes pleurs, \\
& Lorsque je le priais, les yeux baignés de larmes, \\
& De ne pas séparer, du moins dans leur malheur, \\
& Ceux qu'avaient réunis tant de jours de douleur, \\
& Il vendit pour m'avoir ses bijoux et ses armes! \\
& C'est à lui que je dois, dans notre triste sort, \\
& De trouver près de toi, la patrie adorée! \\
& [...]
\end{tabular}

Kind-hearted though he may have been in not separating them at the slave market, Vasco is oblivious of such concerns when he presents Sélika and Nélusko to the Portuguese State Council. They are merely specimens from an undiscovered land, proof of his contention-since their features are neither African, nor Asian, nor Amerindian-that there is another unknown territory yet to be 'discovered' and colonized. He tells the court:

Des esclaves qui sont d'une race inconnue,

Sur le marché des noirs avaient frappé ma vue

En Afrique [...]

[...]

De peuples inconnus ils prouvent l'existence,

Sous le soleil d'Asie ils n'ont pas connaissance,

Ni dans ce nouveau monde aux Espagnols soumis!

$(A$, pp. 52-53)

Though Sélika is initially willing to explain who she is and where she is from, because she cannot deny her adored Vasco any request, at the last minute she observes the more politically astute Nélusko's injunction not to say where her kingdom is located. More than that, she follows his lead and draws attention to her disenfranchised state, declaring that she cannot answer such a question as a slave has no country: 'l'esclave n'en a pas'. Vasco, with his conqueror's mindset, continues to insist, asking the assembled dignitaries to look at his exhibit, pointing out 'les traits de ce visage; | Ces vêtements; ce teint cuivré . . . | Décélant un peuple ignoré' $(A, \mathrm{p}$. 55). That this unknown people is unknown only to the Portuguese and other Europeans is not an observation the assembled dignitaries feel obliged to make, in the security of their Catholic world-view. Yet, in what must be seen as a knowing act of redress on the part of Scribe and

${ }^{8}$ Giacomo Meyerbeer, L'Africaine: partition chant et piano (Paris: G. Brandus \& S. Dufour, [n.d.]), pp. i 1 7-i 9 (emphasis added). Henceforth abbreviated as $A$. 
Meyerbeer, all these certainties are overturned in Acts IV and v, as Vasco and Inèz become representatives of the 'unknown' in an equally hostile and equally theocratic culture where they are the despised aliens; more of which later.

As to the matter of bigotry, the Council to which Vasco makes his address in Act I is made up chiefly of churchmen: the Grand Inquisitor accompanied by no fewer than eight bishops. Only the admiral Don Diégo (who is also Inèz's father), Don Alvar, a nobleman, and Don Pédro, Inèz's intended and the chairman of the Council, act as counterbalance. Meyerbeer and Scribe might just as easily have opted for King Manuel to be a character, indeed the most powerful character, in this scene, and a different type of obstacle might have been invented to bring about the imprisonment of Vasco and Sélika in Act II. The fact that they did not is evidence of their joint desire to invoke a particular vision of sixteenth-century Iberian culture.

This Council listens to Vasco's speech, in support of which he submits a log recounting his experiences, then holds its deliberations in camera. Once left to itself, the Council rapidly divides into three factions. The first, which supports Vasco's enterprise, is made up of his rival in love Don Pedro, who appears to be seduced by the promise of an undiscovered paradise, and Don Alvar, whose tenor tessitura, as well as comments made by the Grand Inquisitor, suggests relative youth, ardour, and optimism. He proves to be Vasco's sterling supporter all the way through. The second faction consists of the admiral Don Diégo, a bass who sees Vasco as a presumptuous upstart and will not suffer to see him aided: 'confier nos vaisseaux, nos trésors, nos soldats | A ce présumptueux que rien n'a fait connaitre' $(A$, p. 64$)$. The third, and most striking, faction is represented by the Grand Inquisitor, also a basso profondo, and his chorus of eight bishops. The Grand Inquisitor condemns the proposed expedition from the outset, without consulting Vasco's log, as heretical. In spite of the new world already discovered by Columbus for the Spaniards, in his view Vasco is 'un impie' and it is heresy to maintain that other unknown worlds exist: 'Soutenir qu'il éxiste est flagrante héresie / Car en nos livres saints il n'en est pas parlé!' ( $A$, pp. 66-67). Don Alvar attempts to counter the ultramontane Inquisitor, but to no avail:

$\begin{array}{ll}\text { DON ALVAR } & \text { Et Christophe Colombe, qui brava l'anathème! } \\ \text { GRAND INQUISITEUR } & \text { Et vous, jeune insensé, vous blasphémez vous-méme! } \\ \text { DON ALVAR } & \text { Je défends ma patrie! } \\ \text { GRAND INQUISITEUR } & \\ & \text { Sans lire ces écrits qui'ils soient livrés au feu! }\end{array}$

The culmination of the Grand Inquisitor's fury is this declaration that Vasco's account should be burnt without being read. Inevitably, and in spite of the apparently favourable disposition of its chairman, Don Pédro, the Council votes to deny Vasco any help. On being told of this decision, he protests and is further condemned by the Inquisitor to perpetual imprisonment in the dungeons of the Inquisition, to which he retorts by condemning the Council in what amount to Enlightenment terms: 
Vous qui redoutez la lumière, Enfermez-la dans ces cachots, De peur que malgré vous elle ne vous éclaire! ( $A$, pp. 78-79)

The finale then finds the two tenors, Vasco and his lone supporter Don Alvar, asserting that it is a 'tribunal aveugle et jaloux', while the three basses counter with 'au rebelle lançons l'anathème' ( $A$, pp. ıо०-о I). Thus Vasco, accused as a rebel and a heretic, in a theocracy which tolerates no disjunction between Church and state and where the power of the state appears to be vested in the Grand Inquisitor, sees his fate sealed.

This confrontation between the forces of light and darkness is enshrined in the tessituras of the different sides. Light is represented by the heavy lyric tenor of Vasco and the lighter lyric tones of Don Alvar. Darkness is incarnated in the three basses. This division of roles is reinforced briefly in the ensemble and chorus which follows Don Alvar's confrontation with the Grand Inquisitor: the tenor bishops take Don Alvar's side and protest with him their opposition to the Grand Inquisitor's stance, while the three bass characters unite with the bass bishops in condemning Don Alvar's temerity. Both groups initially assert that they are entirely motivated by a sense of honour and duty; then, in chorus, they explain their opposing reactions:

$\begin{array}{cl}\text { DON ALVAR } & \text { Témeraire! Témeraire! } \\ \text { avec les } I^{r s} \text { tén. } & \text { De quel droit me faire taire. } \\ & \text { Peu m'importe sa colère } \\ & \text { Et son âge et tout son pouvoir. } \\ \text { L'AMIRAL ET DON PÉDRO } & \text { Témeraire! Témeraire! } \\ \text { avec les } I^{\text {res }} \text { bses; } & \text { Devant moi sachez vous taire } \\ \text { L'INQUISITEUR } & \text { Ou craignez et ma colère, } \\ \text { avec les } 2^{\text {des }} \text { bses } & \text { Et mon rang, mon rang, mon pouvoir! } \\ & \end{array}$

In the second ensemble confrontation, after the votes have been cast and Vasco challenges their decision, Don Alvar continues to support him vocally and verbally while the tenor bishops revert to their original role of underpinning the forces of condemnation and darkness.

The most striking narrative element in this exchange is, without doubt, the introduction of the reactionary Grand Inquisitor and the consigning of Vasco to the Inquisition dungeon at the end of Act I, both incidents entirely fictional. The libretto's harsh portrayal of the Inquisitor and the confessional Portuguese society he upholds may, as with the matter of slavery, have something to do with what White describes as Scribe's 'anti-authoritarian and anti-clerical liberalism, his pragmatic relativism [which] made him suspicious of all absolute creeds' (p. 5I). This is perhaps more in evidence in another Meyerbeer-Scribe collaboration, Le Prophète, completed in I $84 \mathrm{I}$ and premiered in 1849 (Roberts, pp. 208-09). White takes the example of Jean, the prophet of the title, based on John of Leiden ( $1509-36$ ), a charismatic sixteenth-century religious leader who established himself briefly as prophet-king of Münster and espoused a form of proto-communism and polygamy. Interestingly, Scribe's principal source for John appears to have been Voltaire's Essai sur les mours (Roberts, p. 208). In 
the libretto he is depicted as being motivated by love for one woman, questions of honour, and the defence of the weak. As such, he is far from being the fanatical polygamist that the historical John was in reality. White's thesis, however, is that the softening and sanitization of the character serves to 'contrast two forms of idealism, one amorous, the other religious' (p. $5 \mathrm{I}$ ). He explains that for Scribe, mutual acceptance was extremely important and often brought into focus by depictions of the very opposite, bigotry and tribalism:

The ideal of toleration is brought into relief by a depiction of fanaticism comparable with representations of Saint-Bris (in Meyerbeer's Les Huguenots), the Anabaptists (in the latter's Le Prophète (1 849)) [. . .] and the priest of Brahma in Meyerbeer's L'Africaine. (p. 48)

In Act IV of L'Africaine the Grand Bramine requires Sélika, now that she has revealed herself to her people, to observe the rule that all strangers found in her kingdom will be immediately killed:

Jamais, tu l'as juré, jamais nul étranger

Ne souillera de sa présence impie

Le sol sacré de la patrie.

( $A$, p. 305)

At this point Nélusko informs his queen that all the survivors from Vasco's ship have been put to the sword, while the priest who brings this news tells him confidentially that there is one survivor who was found chained up (a late indication here that Pédro's men found time to shackle Vasco before they were overcome) in the bowels of the ship. Nélusko whispers to the priest that he should hurry and catch him, as it might be Vasco: 'cours, qu'on l'immole à l'instant' ( $A$, p. 306): an indication that his murder will, to all intents and purposes, be a religious sacrifice. An instant later, it becomes clear that the method of execution for Inèz and her ladies will be the poisonous vapours of the manchineel tree; followed, it seems, once they are unconscious, by the double-edged sword of justice. When Vasco then appears in the innocence and full glory of his much-anthologized grand air, 'Ô Paradis, sorti de l'onde', Sélika is forced quickly to claim him as her husband in order to save him from the same sword. To Nélusko's rage, the Grand Bramine declares her husband, even if they were married under different laws, to be exempt from execution.

White is correct to identify the Grand Bramine as an example of fanatical intolerance. It might further be argued that his intolerance in Act IV mirrors that of Nélusko in Act II. Nélusko is determined to kill Vasco, initially because he hates all Christians and then because he realizes that his adored queen is in love with this infidel. In Act III Nélusko's previously identified fanaticism is set against the sailors' prayer to St Dominic as they round the Cape of Good Hope, the words of which continue the theme of the religious battle against anti-Catholic heresy in all its manifestations established by that other example of fanatical intolerance, the Grand Inquisitor, in Act I: 'Ô Grand Saint Dominique, effroi de l'hérétique, sur nous veille en ce jour' $(A$, p. 204). Their voyage of discovery is to be a missionary expedition, their aim to overcome the heretic and convert the pagan unbeliever.

In 1852 Meyerbeer asked Scribe to provide a ballad on an Indian theme for 
Nélusko to sing in this act. He wished the character to embody an established series of tropes on the nature of the oriental:

Yoriko [Nélusko] ought to be given a warm language, coloured with oriental images, and with poetic scansion and rhythm that distinguishes him from the Europeans. His character ought to be represented as a mixture of evil, irony and hatred against anything Christian, as well as superstitious veneration, a boundless devotion and intense love for the royal blood of Sélica. To justify his hatred towards the Christians he should be made a priest of a religious fanatical sect, such as a faquir, whose dogma is to hate and persecute any other belief, and who has devoted himself to celibacy, which makes his love for Sélica criminal and impossible. [. . . It would also be musical to let Yoriko speak frequently through proverbs as Orientals often do. (Cruz, p. 47) ${ }^{9}$

In a general sense, of course, Sélika herself, her Malagasy-Indian kingdom, the cult of Brama, and the manner of her death are all redolent of the orientalist vogue which subsumed much of French literature, music, and art in the nineteenth century. None the less, and perhaps not surprisingly given the impact the Lusiadas appears to have had on composer and librettist, Scribe offered not an Indian text but his laughing ballad of Adamastor, based directly on the intervention of the giant as described in Camões's Canto v. 39:
Não acabava, quando hũa figura
Se nos mostra no ar, robusta e válida,
De disforme e grandíssima estatura;
$O$ rosto carregado, a barba esquálida,
Os olhos encovados, e a postura
Medonha e má, e a cor terrena e pálida;
Cheios de terra e crespos os cabelos,
A boca negra, os dentes amarelos. ${ }^{\circ}$

At this point in the plot of the opera, Cruz argues that the introduction of the géant des tempêtes gives Nélusko's self-revelatory set piece a necessary injection of narrative drive and authority. He is a monster with a traceable past, as it were, 'combining a stormy appearance and a striking resemblance to the historical Hottentots, themselves likened by Camões to the Titans' (p. 34; cf. p. 48).

Scribe and Meyerbeer give Adamastor's appearance a significance particular to the ongoing theme of religious hatred; however, Nélusko's ominous description of the giant and his terrible powers seems to celebrate the function of Adamastor as unwitting exterminator of Christian infidels who will face inevitable death at sea:

Le voyez vous?

A la lueur des feux des éclairs,

Le voyez vous, c'est le géant des mers,

Jusqu'au ciel il soulève les eaux,

Mort à l'impie et la mort sans tombeaux!

( $A$, pp. 23I-32)

One might conclude, in the abstract, that it is his 'hatred against anything Christian' which is Nélusko's defining characteristic here, and not necessarily

9 Cruz cites from the French original given in John H. Roberts, 'The Genesis of Meyerbeer's L'Africaine' (unpublished doctoral dissertation, University of California at Berkeley, I 977), p. I I I .

10 Emanuel Paulo Ramos, 'Os Lusiadas'de Luiz de Camões (Oporto: Porto Editora, I 987), p. 202. 
his orientalized otherness. In performance, however, the ballad of Adamastor proved profoundly unsettling to the Paris audience at the opera's premiere, with this Act III section incurring round condemnation, which Cruz (pp. 7072) ascribes to musical rather than textual issues.

The actions of the Grand Bramine and his flock of sword-wielding fanatics in Act IV mirror almost exactly those of the Grand Inquisitor and his band of episcopal acolytes in Act I, with Nélusko's intervention and the Portuguese sailors' chorus in Act III offering a linking passage and a microcosm of the opposition of these two belief systems. The forbidding bass prelates bookend the action in several ways: each is the chief priest of an oppressive, authoritarian belief system whose most salient characteristics appear to be the requirement for absolute, unquestioning obedience and the liberal application of cruelty and injustice as a means of maintaining its position of pre-eminence. What might be less immediately obvious is that the Council in Lisbon which condemns Vasco, and the Inquisitor with his dungeons, are, equally, manifestations of another wing of the orientalizing tendency: an exoticization of Iberia which involved the invocation of a black legend of the Spanish/Portuguese Inquisition and the culture of auto-da-fé. In mid-nineteenth-century French grand opera, $L$ 'Africaine was certainly not the only such manifestation.

After his experience with Les Vêpres siciliennes (I 855), Verdi was reluctant to write another grand opera for Paris. Indeed, in a letter to the music publisher Léon Escudier of 19 June ${ }^{8} 86_{5}$ he expressed his horror at the prospect, partly because of Les Vêpres, but he appears also to have been appalled by the extravagant and demanding behaviour of Meyerbeer's widow in the lead-up to the premiere of L'Africaine. ${ }^{\text {II }}$ However, on 21 July I $^{2} 6_{5}$ he responded positively to a request from Émile Perrin, the new director of the Académie Impériale de Musique, to consider a scenario by Joseph Méry and Camille du Locle based on Schiller's Don Carlos, and stipulated, in particular, that there should be a 'short scene between Philip II and the Inquisitor; the latter blind and very old'. ${ }^{12}$ L'Africaine had been premiered on 28 April of the same year, to tremendous popular success. ${ }^{13}$ While it would be invidious to suggest a direct link, none the less, the appearance of a Portuguese Inquisitor may well have marginally influenced the very deliberate inclusion of a Spanish one. Indeed, Julian Budden goes so far as to suggest that the 'stress on the bass timbre to the point of exaggeration' in what Verdi termed the 'Inquisition Scene', his encounter between Philip and the aged Grand Inquisitor, must indeed be related to the finale in Act I of L'Africaine. ${ }^{14}$ It is also the case that Verdi had visited Philip II's great monastery-palace of the Escorial in 1863 and been profoundly affected, not to say distressed, by it. ${ }^{15}$ Thus the Spain he finally agreed to engage with, in the Méry-du Locle scenario for Don Carlos, does not just take

\footnotetext{
II Elizabeth Giuliani, 'Genèse et élaboration à travers la correspondance', L Avant-Scène Opéra, 90-I (March 1990), I8-27 (p. I8).

${ }^{12}$ M. Elizabeth C. Bartlett, 'From Rossini to Verdi, in The Cambridge Companion to Grand Opera (see Roberts, above), pp. 258-90 (p. 282).

${ }_{13}$ Roberts, pp. 222, 232.

${ }^{14}$ Julian Budden, The Operas of Verdi, 3 vols (London: Cassell, i 973-8I), III: From 'Don Carlos' to 'Falstaff' (198I), p. I 23.

${ }^{15}$ André Lischke, 'Quel Don Carlos', L'Avant-scène opéra, 90-9I (March 1 990), 48-1 33 (p. 49).
} 
in what André Lischke terms 'l'Espagne exotique, arabisante, pleine de sève folklorique, incarnée au $\mathrm{II}^{\mathrm{e}}$ acte par Eboli et ses compagnes, bref, l'Espagne des espagnolades' ( p. 49), which he had already put on stage in operas such as Ernani and Il trovatore, for example, but also the darker vision of

l'Espagne de la religiosité austère, cruelle, inséparablement liée à l'absolutisme du pouvoir politique, et dont le prosélytisme exige des mises en scène aussi spectaculaires que barbares; l'Espagne sur laquelle plane l'ombre de Torquemada et de ses successeurs, l'Espagne des bûchers de l'Inquisition. (p. 49)

There is no question that the encounter between the King and the Grand Inquisitor is one of the pivotal moments, if not the pivotal moment, of the Schiller play, and the same may equally be said of Verdi's Don Carlos. Verdi's Grand Inquisitor is, of course, with such a pedigree, a much more nuanced, more highly political figure than either of Meyerbeer's religious patriarchs and he is also infinitely more powerful musically. The dark orchestration Verdi composed for his encounter with Philip of Spain, as Bartlett observes, confirms his dominance in unequivocal terms:

In this struggle between Church and State, the orchestra informs us who is in control: it is the Inquisitor's motif that dominates to the last. An exceptional extended dialogue between two strong-willed individuals, not a conventional duet. They neither agree nor sing together. Their emotional reactions, especially the king's, run the gamut: hence the wildly fluctuating tempi, melodic styles and dynamics, all reflected, supported and interpreted by the orchestra. (p. 287)

Both Anthony Arblaster ${ }^{16}$ and, before him, George Martin stress that Verdi's portrayal of the Church as a malevolent political entity is rooted in his own anti-clericalism and in the political events of the years just before the opera's premiere. As far as Martin is concerned, it is the strength of Verdi's anticlericalism which introduces one of the major plot differences from the Schiller original. In the Schiller play the King orders the assassination of Posa; Martin argues that in the opera the libretto makes it clear that the assassination is ordered by the Grand Inquisitor and carried out by his henchmen/guards, whatever fudging there may have been in performance. ${ }^{17}$ Thus, Arblaster's view that the opera is about European politics-conditions and events in France and Flanders in the mid-sixteenth century in the period in which the opera is set and the politics of State and Papacy in France and Italy in the midnineteenth century, with the Spain of Philip II as a convenient and rather dramatic backdrop-reflects the consensus.

Even so, and rather unsurprisingly, the portrayal of the Grand Inquisitor and Philip's treatment of him attracted accusations of anti-Catholicism against Don Carlos. Arblaster mentions the famous episode of the Empress Eugenie:

the Empress Eugénie, who attended the 1867 premiere, turned her back on the stage during the scene between the king and the Grand Inquisitor, reportedly at the moment when the king tells the cleric to be quiet: 'Tais-toi, prêtre'. Even as late as I950 the opera was picketed in New York by protesters who objected to its anti-Catholicism. (p. 138$)$

${ }^{16}$ Anthony Arblaster, Viva la Libertà!: Politics in Opera (London: Verso, I 992), pp. I33-41 .

${ }_{17}$ George Martin, 'L’Église et Don Carlos', L'Avant-scène opéra, 90-9 I (March I 990), I 53-55 (p. I 53). 
Martin suggests that this gesture may, more than anything else, have decided the French opera-going public against an opera which, in all other respects, was deemed a qualified success. ${ }^{18}$

The demonization of the Portuguese Catholic Church, on the other hand, in the Meyerbeer-Scribe collaboration seems rather less deliberate and less easy to categorize. On the one hand, it is balanced by an equally harsh, equally exoticized portrayal of fanaticism by the adherents of Brama in Sélika's kingdom, and, on the other, its anti-clericalism is part of a recognizable Meyerbeer-Scribe pattern which also includes other important collaborations such as Le Prophète and Les Huguenots. It is also perhaps inevitable that there should have been little distinction drawn between the functions and powers of the Inquisition in Spain and in Portugal, especially as Scribe's original proposal for L'Africaine ( $1843^{-50}$ ) involved 'the unhappy love and adventures at sea and in Africa of the Spaniard Fernand, who pursues his beloved to Mexico only to find himself at the mercy of his own African slaves on the coast of the Niger' (Cruz, p. 32). Vasco and Fernand were both Iberian colonial adventurers, after all.

The final theme relating to the representation of the Spanish and Portuguese colonial enterprise at this time, which L'Africaine holds in common with another Verdi opera on a Spanish topic, La forza del destino, is that of the impossibility of interracial love. La forza del destino is based mainly on an adaptation of the Duque de Rivas's Romantic drama Don Álvaro o la fuerza del sino ( 1835 ), with an interpolated scene from Schiller's Wallensteins Lager (1795), by the librettist Francesco Maria Piave. While the action of Don Álvaro and La forza takes place in mid-eighteenth-century Spain and Italy, both have for background story, albeit in a rather hazy and oblique way, the Peruvian struggle for independence from the Spanish Crown, in that this struggle explains the hero's state as a mysterious and orphaned exile in Spain. ${ }^{19}$

In the first version of Verdi's opera, premiered in St Petersburg on ro November I862, Donna Leonora de Vargas is in love with the enigmatic but wealthy and valiant Don Alvaro, secretly the son of a Spanish Viceroy in Peru who married the last Inca princess and who, in revolt against the Spanish Empire, attempted to claim the kingship of Peru in her name. Since the last Inca princess, Beatriz Nusta, married Martín de Loyola, the nephew of the Jesuit founder St Ignatius Loyola, in I 558, this is, of course, a chronological and political impossibility. Indeed, while mestizo marriages and other unions between conquistadores and Inca royalty were accorded all the honours of aristocratic intercourse in the period immediately succeeding conquest in Peru, from the mid-sixteenth century, as administrators from Spain took the place of conquistadores in the seats of power, the mestizo products of these unions were

\footnotetext{
${ }^{18}$ Martin, p. I 55; for press response to Don Carlos, see Catherine-Marie Heuls, 'La création de Don Carlos au feu de la presse', L'Avant-scène opéra, 90-9 I (March 1990), I 56-59.

${ }_{19}$ The Italian military scenes in Don Álvaro o la fuerza del sino take place in Veletri, near the place where in 1744 Austrian Imperial forces were defeated by Spanish and Neapolitan troops led by Carlos de Borbón, King of Naples. Although there were sporadic Inca, or at least Indian, uprisings over the entire period of colonization, the last in 18 I 4 , Peru achieved independence only in 1824 , a year after Brazil and long after the action of this plot had reached its conclusion.
} 
relegated to second-class citizenship. ${ }^{20}$ There could be no question of such a union in eighteenth-century Peru.

These matters notwithstanding, in the opera Don Alvaro's father and mother were captured and imprisoned for life; their child, born in jail, was raised in the wilderness. In the Rivas play a younger brother of doña Leonor, don Alfonso, absent from the opera libretto, reveals Álvaro's secret. His father and mother escaped to live with 'los indios salvajes' until Álvaro was born. ${ }^{21}$ When they were imprisoned he was left to be raised by his mother's people:

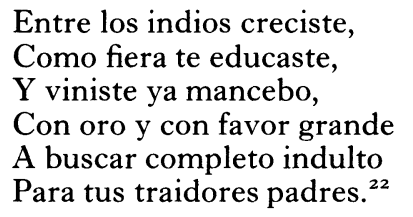

The opera libretto, in the absence of don Alfonso, has Alvaro reveal his own identity in soliloquy while a soldier in Italy:

Della natal sua terra il padre volle
Spezzar l'estranio giogo, e coll'unirsi
All'ultima degl'Incas la corona
Cingere confidò . . . Fu vana impresa!
In un carcere nacqui; m'educava
Il deserto; sol vivo perché ignota
È mia regale stirpe!

(Act III, sc. I)

In this version he was born in jail and raised in the desert and is alive only because his lineage is unknown in Spain.

Unable to reveal his true parentage once he entered Spanish society, don Álvaro was none the less destined to carry the double stigma of being both an outsider of dubious origin and a mestizo. Because of these factors, in the opera the Marquis of Calatrava, Leonora's father, has declared Don Alvaro unfit to marry one of her breeding, and she, in response, has resolved to elope with the man she loves. However, fate, the awful forza, steps in. Alvaro kills the Marquis by accident and he, in turn, curses his own daughter as he dies. Alvaro and Leonora flee, losing each other in the mêlée. She, believing he has been killed by her father's men, finds sanctuary in the (male) Convent of the Angels in an isolated cave disguised as an anchorite monk. Alvaro flees and enlists under a nom de guerre in the Spanish army in Italy, only to be discovered there by Leonora's brother Don Carlo, who briefly becomes his good friend until it dawns on him who this man is. They attempt to fight a duel and are dispersed by other soldiers, whereupon Alvaro resolves to leave the world and,

${ }^{\circ}$ See David Brading, The First America: The Spanish Monarchy, Creole Patriots and the Liberal State 1492-I867 (Cambridge: Cambridge University Press, 1991), pp. 255-72.

${ }_{21}$ 'In the understanding of the colonial period in Latin America, un indio salvaje or un indio bárbaro means one not converted to Christianity and living in tribal communities unaltered by European influence' (Carmen Fracchia, 'Depicting the Iberian African in New Spain', in Mexico r680: Intellectual and Cultural Life in the Barroco de Indias, ed. by Jean Andrews and Alejandro Coroleu (Bristol: HiPLAM, forthcoming), pp. 37-5o (p. 45)).

${ }_{22}$ Don Álvaro o la fuerza del sino, ed. by Alberto Sánchez (Madrid: Cátedra, I 988), 11. 22 I 2-I 7. 
unwittingly, joins the same convent as Leonora. Don Carlo traces him there, provokes him to a second duel, and is himself mortally wounded. As this duel takes place outside Leonora's cave, Alvaro summons the 'hermit' to aid the dying man. Carlo, recognizing his sister, presumes that she and Alvaro have been living there in sin all along and stabs her to death. Alvaro then sees that it is Leonora and, in absolute despair, throws himself off a nearby cliff. This apostate climax, an important element in the Rivas play, was faithfully retained in the first version, but Verdi was uneasy with this ending in terms of the plot and with the music he had composed for the last act. He consequently withdrew the opera after the Rome premiere in 1863 . In 1868 he was asked to produce a revised version and, with Ghizlanzoni finally altering the ending of Piave's original plot, he wrote an entire new final scene as well as making other changes to the piece. The crucial plot alteration involves Alvaro's acceptance that he must continue to live in expiation of his sins, and thus the final scene is one of Christian reconciliation rather than ultimate despair. ${ }^{23}$ The new version was given at La Scala on 27 February 1869.

One further, and much lesser-known, work is worth mentioning in this context: the Brazilian Antônio Carlos Gomes's adaptation of a novel by his countryman José Martiniano de Alencar, O Guarani (1857). The opera version, in Italian with a libretto by Antonio Enrico Scalvini and Carlo D'Ormeville, an important Italian theatrical agent of the time, was premiered at La Scala in 1870 as Il Guarany, and received a warm welcome both in Italy and subsequently in Brazil. In the opera plot the love story between Peri, a noble Indian prince, the Guarany of the title, and Cecilia, the daughter of a Portuguese conquistador, ends happily. In the Alencar novel it does not; the lovers appear to float off towards their deaths together in the midst of a catastrophic flood after a series of hair-raising adventures. ${ }^{24}$

In purely plot terms, in $L^{\prime} A$ fricaine Sélika saves the life of her beloved master twice, yet her love and generosity will not be returned. At the end, albeit at her own behest, the black Indian queen is left to inconsolable and terminal grief, a fate reminiscent of that of another black queen, Dido. ${ }^{25}$ However, there is little in the legend of Dido, as represented in Purcell or in Berlioz, which draws attention to Dido's skin colour or racial identity. She remains in both pieces a tragically deserted queen in an environment where the cultural difference between Rome and Carthage is rendered minimal, whereas L'Africaine makes very clear the enormous cultural, racial, political, and religious gap between Sélika and Vasco. Thus, though the Queen of Carthage would have had a certain prominence in the consciousness of the Parisian opera-going public in the mid-I 86os, since Berlioz's Les Troyens à Carthage was premiered in Paris in I 863, it is surely the case that the more apt comparison would have been made some years later after the premiere of Verdi's Aida in $187 \mathrm{I} .{ }^{26}$ Here, however, the

${ }^{23}$ See Julian Budden, 'La forza del destino', in The Operas of Verdi, II: From 'Il trovatore' to 'La forza del destino' (1978), pp. 425-522.

${ }^{24}$ See my 'Carlos Gomes' Il Guarany: The Frontiers of Miscegenation in Nineteenth-Century Grand Opera', Portuguese Studies, 16 (2000), 26-42, for a full account of this opera and a discussion of factors which may have had some influence on the happy outcome of the love story.

${ }^{25}$ See Roberts, pp. 227-28, for a comparison of Sélika's and Dido's death scenes.

${ }^{26}$ Les Troyens was composed in $1856-58$, and first performed in two parts as two separate 
love triangle works the other way. Radamès, who must be considered the whiter, hegemonic party in this equation, is loved by the Pharaoh's daughter Amneris, but he in his turn loves the enslaved black Ethiopian princess Aida. Though, ultimately, he prefers death in her company to life with the Egyptian princess, it cannot be considered a successful love union since there is no societal acceptance of their partnership and no future together for them in the life either of Egypt or even, had they escaped successfully, of Ethiopia. While Sélika's culture appears accommodating enough to be able to allow the alien Vasco a place as consort to its queen, the structure of the love triangle established by Meyerbeer and Scribe renders its success impossible.

Aida ends with a love duet between Radamès and Aida in the tomb, L'Africaine with a duet between two disappointed lovers: Sélika, who has lost Vasco to Inèz, and Nélusko, who is about to lose Sélika and probably himself to the manchineel. Rather interestingly, the failure of the Sélika-Vasco relationship in L'Africaine, while ostensibly due to Vasco's previous love for the loyal and self-sacrificing Inèz, may, in a more subtle sense, be attributed to Vasco's failure to convince as a Romantic hero. Roberts is quite trenchant on the subject of Meyerbeer's failure to ignite the character of Vasco. In particular, he points to the 'insipidity of Meyerbeer's music' in the second part of Vasco's grand air, which, at this juncture he sees as having more to do with the 'pathetic character' of Vasco than any 'stupidity' that might be ascribed to Scribe's text (Roberts, p. 230).

In this second part Vasco, now captured by Sélika's people, begs them to take him to a (presumably Portuguese) ship he has rather conveniently espied off the coast, so that he may inform the crew on board that he did indeed discover a new world as promised. Then they may execute him. In this way, at least his exploits will be recounted to the Portuguese court, just as he himself reported the episode of Dias's heroic demise. While he pleads with the servants of Brama to have pity on his memory, since 'c'est mourir deux fois, que perdre ensemble la vie et l'immortalité', there is not a word on the fate of his supposedly beloved Inèz $(A, \mathrm{p} .3 \mathrm{I} 8)$. Although in the following exchange with the Grand Bramine, on learning that she and her ladies have perished, he grandly instructs them to 'frappez donc!', it is nevertheless clear that his place in posterity is by far the greater loss. Then, while his acceptance of Sélika's declaration that he is her husband and his participation in a marriage ceremony which involves imbibing a love potion are perhaps justifiable, as he believes Inèz to be dead and would otherwise be dead himself, his behaviour towards both Inèz and Sélika subsequently borders on the despicable. Indeed, it is worth noting that the two Portuguese lovers have a strangely malleable attitude to marriage in this opera. Inèz weds Don Pédro to free Vasco and Vasco marries Sélika to free himself. Such an attitude surely cannot indicate much of a propensity towards passion in either, and of course the fact that Meyerbeer, Scribe, and the other

operas, La Prise de Troie and Les Troyens à Carthage, with the latter first performed at the Théatre Lyrique in Paris in I863: John Hamilton Warrack and Ewan West, The Oxford Dictionary of Opera (Oxford: Oxford University Press, I 992), pp. 71 9-20. The matter of Dido/Didon's blackness is not alluded to in either the Purcell or the Berlioz text. 
librettists did not come up with a duet between Vasco and Inèz rather attests to the sterility of their relationship.

At the end of Act IV Vasco hears Inèz and her ladies under the manchineel even as he is being summoned by his new wife to consummate their union. $\mathrm{He}$ thinks it is some kind of supernatural event, probably because he is still under the influence of the love potion. The act then ends with a chorus of Indian ladies celebrating the passion of Vasco and Sélika, Vasco having an intimation of Inèz's presence while he goes to Sélika, and Inèz, first with her ladies and then on her own, bidding farewell to her land: 'Adieu mon beau rivage' ( $A$, pp. $37 \mathrm{I}-75$ ).

When Act v opens with Vasco gone and Sélika convinced she has been deserted, Inèz promptly turns up to explain to her that she encountered Vasco, who was himself distraught to see her still alive now that he was married:

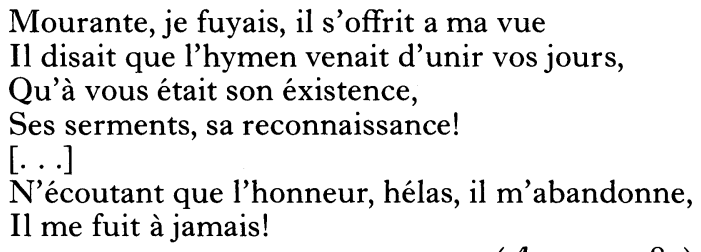$$
\text { ( } A \text {, p. 379-80) }
$$

At this point it appears that Vasco has, in effect, abandoned both women. He is still on the island, however, and, after her interview with Inèz, Sélika orders Nélusko to escort her and Vasco onto the Portuguese ship which is still off the coast and leave her kingdom for ever. She then proceeds to her death.

As Roberts notes, Vasco's desertion of Sélika began to concern Meyerbeer after Scribe's death, so much so that 'he had Birch-Pfeiffer and Duesberg prepare an alternative final scene in which Vasco returned to Sélika and she died in his arms, but there is no evidence that he ever set it' (p. 229). Even more interesting is the fact that Meyerbeer died with the score indicating that Vasco was to be dismissed by Sélika, and that it was Fétis who revised the score so that Vasco simply disappeared (Roberts, ibid.). Perhaps it seemed that Vasco's dignity, the dignity of the Romantic hero and a hero of the European colonial enterprise, would thus not be so thoroughly compromised.

Yet the music Meyerbeer wrote for Vasco and Sélika, their duets in Acts II and IV, and the fact that there is almost no musical interaction between Vasco and Inèz, tell a different story, one that runs contrary to the narrative ordained by the libretto which he designed with Scribe. The single set-piece interaction between Vasco and Inèz takes place in the Act II finale after his release from jail, and is probably more significant for Vasco's cruelty to Sélika than his demonstration of love for Inèz. Overcome with emotion, Inèz tries to tell him she has agreed to marry Don Pédro. He does not listen to her, but instead suspecting that she thinks him in love with Sélika, theatrically gives Sélika to her to prove that she, a mere slave picked up in Africa, means nothing to him. That this happens in Sélika's hearing and in the wake of his first duet with her is significant. The intimacy of the duet is due to the fact that she tells him of the existence of Madagascar, thus solving the major navigational problem 
he encountered on his last voyage. Textually, then, he speaks of his gratitude to her and his desire to be reunited with Inèz; but, as even Roberts notes, there is in the music a 'nascent sexual interest that the composer surely did not intend to suggest' (p. 229). Perhaps it might be better to argue that this was not ordained in the libretto, but it is certainly conveyed in the intensity of this duet and in the second duet, in Act IV, which, though it may have as its textual justification the consumption of a love potion, is a highly charged and erotic exchange, undoubtedly, as Roberts notes, 'one of the high points of the score' (p. 227). In fact, his dismissal of Sélika in Act II may more coherently be read as a covert admission of his attraction to her, an attraction doubly embargoed, by his previous commitment to Inèz and by the matter of her colour and enslavement.

If the libretto plots the ultimate success in love of the aristocratic Portuguese Inèz, the music contradicts it by giving both of the love duets with Vasco and a moving, elegiac death duet with her servant Nélusko to the black, formerly enslaved, Indian queen. The I $86_{5}$ Paris audience witnessed an opera whose Portuguese Discoverer hero left the scene under suspicious circumstances at the end of Act IV, leaving the two women in his life, one his wife and the other his sweetheart, each incarnating one of the two cultures pitted against each other in the narrative, to fight it out and display the nobility and magnanimity so conspicuously absent in his behaviour. Sélika orders events so that Inèz can be reunited with Vasco, having them transported to the Portuguese ship which will take them from her kingdom and then, by her death, releasing Vasco to marry again. The interracial union cannot prosper and the plot ensures that it does not, but the music tends in a different direction entirely. While one convincing explanation, pace Roberts, may point to Meyerbeer's inability to create a truly credible Romantic hero as the reason for this failure, another identifies a crucial tension between words and music, one which lies across the issues of race, religion, slavery, and imperialism which informed the cultural life of the mid-nineteenth century in France. 